\title{
Necrology: Professor P.R. Sharma (1950 - 2020)
}

Rana P.B. Singh ${ }^{+}$

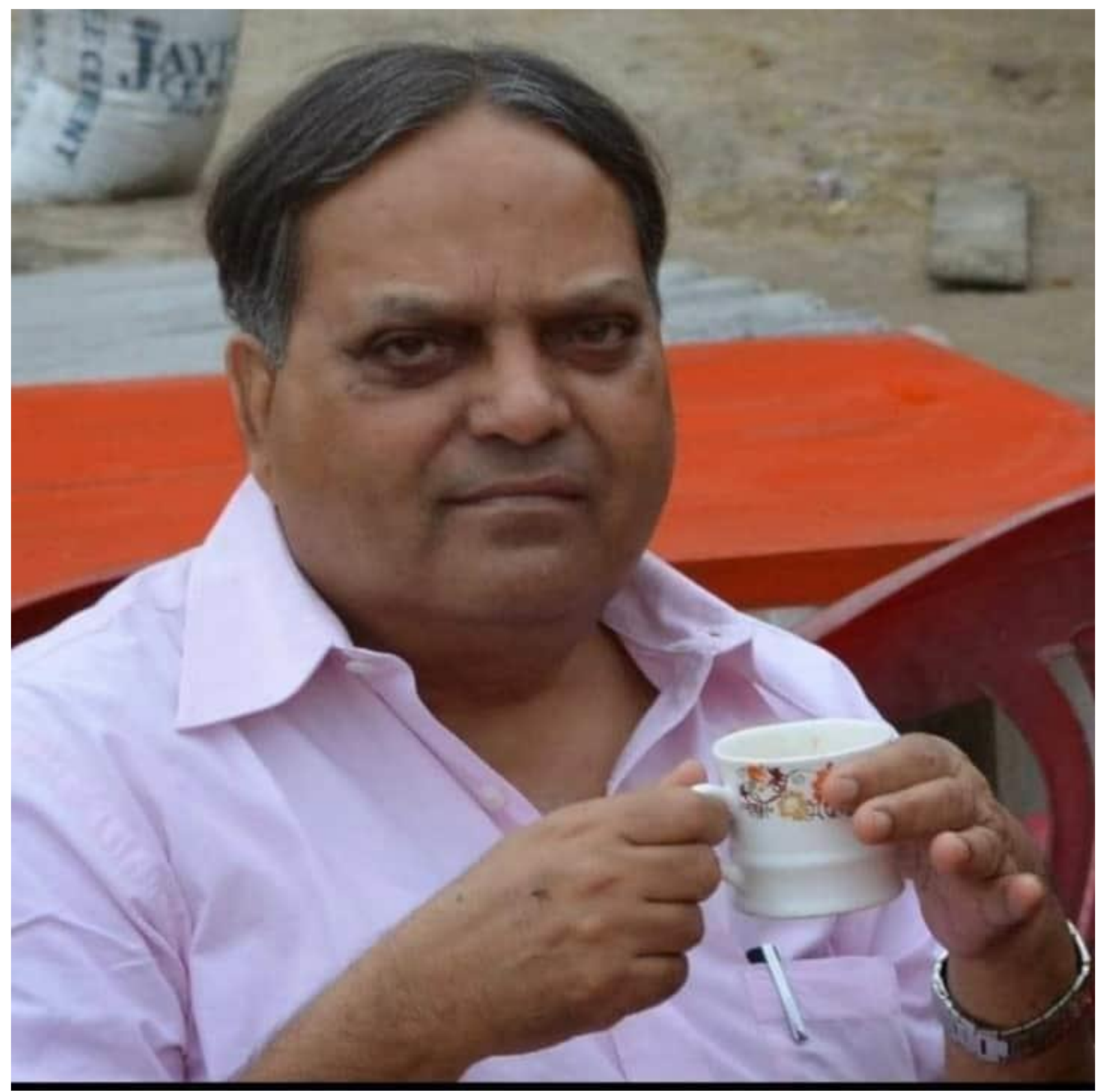

P.R. Sharma, $1950-2020$

An eminent geographer and regional planner 2077). It was a shocking news as he was not from the Banaras School of Geography (India), suffering by any serious ailment. In the mid night Professor Parasu Ram Sharma passed away due he felt uneasy and called his student and to massive heart attack at 01:34AM on 29 July colleague, Akhilendra Tiwari, to take him to the 2020 (Shravan Shukla 10th Vikrama Samvata hospital. Unfortunately, after reaching Heritage

\footnotetext{
${ }^{\dagger}$ Former Professor \& Head- Geography, B.H.U., Varanasi \& President ACLA- Asian Cultural Landscape Association. Email: ranapbs@gmail.com

(C) 2020 Singh. This is an Open Access article distributed under the terms of the Creative Commons Attribution License (http://creativecommons.org/licenses/by/2.0), which permits unrestricted use, distribution, and reproduction in any medium, provided the original work is properly cited.
} 
Hospital, located at Lanka, Varanasi, he had his last breath before doctors could do any medical help. His body was kept in the mortuary; his cremation was performed on 30 July 2020 at 11:30AM at Harishchandra Ghat (Varanasi), and 'Mukhagni' ritual was offered by his son, a software-Engineer, Amit Sharma (Bengaluru) and his biochemistry-researcher daughter $\mathrm{Dr}$. Ms. Soma Sharma (Kolkata); his wife Smt. Savita Sharma was also present there.

A webinar condolence was held in his alma mater, the Department of Geography, Banaras Hindu University, on 31 July 2020 at 04:30PM in the presence of several colleagues and students. On behalf of the department, the Head of the Department Professor R.S. Yadava presented a deeply touching message of grief, followed by Professor V.N. Sharma, who happens to be Professor P.R. Sharma's first PhD student. Professor V.N. Sharma narrated experiences with his Guru and his life sketch. Professor Rana P.B. Singh, retired Professor \& Head, Department of Geography, Banaras Hindu University, and his closest friend since 1968 and colleague for the longest period) spoke about Professor P.R. Sharma's contributions to geography, his role in the initiation of 'new traditions in geography', his leading role in publishing festschrift volumes honouring the retired teachers (already released in honour of Professor N.K.P. Sinha, and Professor Kashi N. Singh), promotion of Indo-Polish collaboration, structuring the outline of afresh courses, etc., and also his personal friendship and his personal help and support. The condolence ended with 2minutes silence and prayer to the Almighty for granting peace to the departed soul of Professor P.R. Sharma, and courage to all the family members to adjust with this irreparable suffering. For all of us, this has been a significant loss. For me, this turned to be a big vacuum in my academic and social life, being the oldest and intimate friend since 1968. On the line of Hindu thought, we pray to the Almighty Shiva to grant peace to the departed soul and courage to his family members (son Amit Sharma, daughter Soma, and wife Savita) to get relief from this greatest loss. Shradhanjali (intimate homage) with tears and pain.
Professor P.R. Sharma (born: 08 November 1950 in the village Karon, Ballia district, state of Uttar Pradesh; died: 29 July 2020, Varanasi), had been awarded M.A. (1970) and Ph.D. (1977) degrees from Banaras Hindu University, both under the supervision of Professor R.L. Singh (1917-2001). He had joined this department as a lecturer in August 1974, became Reader (Associate Professor) in April 1985, and promoted to a Professorship in July 1998. He had been Head of the Department of Geography, Banaras Hindu University from 01 February 2004 to 31 January 2007. He retired on 30 June 2016, and after living about six months in his flat (Swastika Tower at Lanka, Varanasi), together with his wife he had shifted to Bengaluru live with his son and his family. On 30 January 2020, with his wife he returned to Varanasi, to again re-join his old community life in Varanasi. Akhilendra Tiwari, once his doctoral student and presently a faculty in Veer Kunwar Singh University (Bihar), was regularly visiting him and taking care of the family.

Professor Sharma stayed in England (1982-83) as a Commonwealth Academic Staff Fellow at the University of Sussex and attended International Conferences and Seminars in the University of Oxford and Sussex. He had participated in more than three dozen of the national and international seminars, including one at Warsaw, Poland. He was Convenor of an International Seminar on 'Regional Policies and Development in the Third World': December 1991, and also of a National Seminar on 'Indian Geography in the 21st Century': March 2005, both held at Banaras Hindu University, Varanasi. He had also served as an Honorary Editor of the National Geographical Journal of India; President of the National Geographical Society of India; and also, Secretary-General of the South Asian Geographers Association (SAGA) during 1986-1994.

Professor Sharma has published about 70 research papers in India and abroad. He has edited five anthologies. His special interest were Regional Planning, Resource Geography, Rural Development and Human Settlements. Twelve students were awarded Ph.D. degrees under his 
supervision. He was a life member of National Association of Geographers, India (NAGI) and National Geographical Society of India (NGSI). Two of his early papers dealing with spatial organisation model for rural development, and growth centres and regional development, both illustrated with a detailed investigation of Chhatishgrarh, and published in the internationally acclaimed journal, Habitat International (Pergamon, Oxford, Volume 8, 1984) considered as a benchmark in the studies of regional development. He had further expanded his approach toward population and resource appraisal, a critique of policies and planning strategies, and finally, sustainable development. He has also co-edited a volume on Interdisciplinary Advances in Geography, based on a multidisciplinary national seminar organised by him.

Professor Sharma was known as one of the best teachers, who always used the latest data and debate in his teaching and discourses. 